\title{
Participation of Dog Owners on Rabies Prevention in Medan, Indonesia
}

\author{
Rona Meilysa Pasaribu ${ }^{1}$ \\ Department of Health Education and Behavioral Sciences \\ University of Sumatera Utara \\ Medan, Indonesia \\ ronameilysa@gmail.com
}

\author{
Ida Yustina ${ }^{2}$ \\ Department of Administration and Health Policy \\ University of Sumatera Utara \\ Medan, Indonesia \\ idayust@yahoo.com
}

\author{
Taufik Ashar ${ }^{3}$ \\ Department of Environmental Health \\ University of Sumatera Utara \\ Medan, Indonesia \\ doctta@gmail.com
}

\begin{abstract}
Indonesia has an average of 197 cases per year of human rabies deaths in the last 5 years. We investigated sociodemographic, knowledge and attitudes related to rabies that influenced participation of dog owners on rabies prevention through the interviewed based questionnaire. This research was conducted descriptively with approach of cross sectional method to $72 \mathrm{dog}$ owners in subdistrict Medan Tuntungan based on purposive sampling process. The relationship between characteristic of dog owners and their participation in rabies prevention analyzed using Pearson's correlation analysis. Over $75 \%$ of respondents owned domestic dogs (average of 2 dogs per household), more than $68 \%$ knew that rabies is transmitted through dog bites. As much as $\mathbf{5 0 \%}$ of respondents knew of dog vaccination as a means to control rabies, but only $37,5 \%$ vaccinated their dogs although they know that annual dog vaccination activities have been implemented to vaccinate all dogs free of charge. The participation of respondents in prevention of rabies disease is in the moderate category is $\mathbf{5 0}$ respondents $(69,44 \%), 9$ respondents $(12,5 \%)$ is in the low category, but only 13 respondents $(18,06 \%)$ is in the good category in their participation. There is a strong significant correlation between knowledge, attitude $(p<0.01)$ and a significant correlation on educational $(p<0.05)$ of dog owners with their participation in rabies prevention. This reflects the urgent need for advocacy programs to raise rabies awareness among the community. However, close intersectoral collaboration between the medical sector, veterinary, and integration of local authorities to ensure the availability of preventative service, also the public health to conduct health promotion of rabies prevention program, is a key element to eliminate deaths from canine rabies by 2030 .
\end{abstract}

Keywords-participation; canine rabies; rabies prevention program; intersectoral collaboration; health promotion

\section{INTRODUCTION}

Rabies is one of the oldest zoonotic diseases and when it shows clinical symptoms in animals or humans will always ends with death, Case Fatality Rate (CFR) reaches $100 \%$ by attacking at all age and gender [1]. The disease is caused by a viral infection from genus Lyssavirus (familia Rhabdoviridae) [2] and is most $>99 \%$ transmitted to humans by domestic dog bites. Despite being entirely preventable, canine rabies still kills 59,000 people every year with the majority of victims occurring in Asia (59.6\%) and Africa (36.4\%); $40 \%$ of individuals bitten by suspected rabid animals are children under 15 years of age [3]. Within this region, Indonesia has the fifth largest number of human rabies cases after India, China, Bangladesh and Pakistan, with 197 cases reported per year but the coverage of dog vaccination was only $23.80 \%$ with Post Exposure Prophylaxis (PEP) of 242.725 cases/year [4].

The World Health Organization (WHO), The Food and Agriculture Organization of the United Nations (FAO) and World Organization for Animal Health (OIE) and rabies stakeholders from around the world held a conference in Geneva that resulted in a global elimination program of dogborne rabies diseases ( 0 cases) by 2030 , this program is known as "End Rabies Now" with the motto "Rabies 99.9\% deadly, but $100 \%$ preventable" [5]. Previously the ASEAN countries have committed to elimination of dog-transmitted rabies deaths by 2020 [6].

Indonesia Health Profile reported total number of Animal Bites Transmitting Rabies (ABTR) as many as 80,433 cases, there are 25 provinces infected by Rabies from 34 provinces in Indonesia. Most cases of ABTR occur in Bali as many as 30,595 cases; followed by North Sulawesi as many as 4.135 cases; and the third largest number of ABTR is North Sumatera as many as 3.775 cases [4] with 102 cases of Lyssavirus positive and 23 cases of human rabies death [7].

Medan is one of the city in North Sumatera with high rates of ABTR cases. There were 283 cases of ABTR with division of 142 men and 141 women, with 11 cases positive status of Lyssavirus. It was reported that subdistrict Medan Tuntungan had the highest ABTR cases in 2016 compared to other subdistricts, which were 56 cases of dog biting with 3 cases positive status of Lyssavirus [8]. Medan Tuntungan covers an area of $15,624 \mathrm{~km}^{2}$ with more than 3.228 of human 
population. The main socio-economic activity is factory laborers, livestock and agriculture which dogs are used to guard the crops [9].

Although Indonesia is predominantly Muslim (practicing the Islamic principles in which it is prohibited to eat dog meat or keep dogs inside the house), half of people in Medan Tuntungan are Christian. Dogs have a high cultural and economic value in Medan Tuntungan [9]. Dogs breeding in Medan Tuntungan also influenced by the habits of the people who still like to eat dog meat as daily meal or with belief as a medicine, there is found 26 restaurants that provide a main menu of roast dog. Dog meat also a popular menu item in certain traditional ceremonies.

Based on preliminary survey from individual form data reports of ABTR and Lyssa cases in Medan, there are 227 cases $(80 \%)$ from 283 cases of ABTR in Medan and 46 cases $(82 \%)$ from 56 cases of ABTR in sub-district Medan Tuntungan, recorded the status of dog ownership that have been bitten is one's own, belonging to neighbors or own of family is very dominantly than stray $\operatorname{dog}[8]$, this shows the high maintenance of dogs in Medan is not balanced by the

\section{METHODOLOGY}

This research was conducted descriptively with approach of cross sectional method in sub-district Medan Tuntungan 2017 that using questionnaires consist of three section about socio-demographic, knowledge, attitude, and participation. Tabulated and classified all the answers, later given score of answers according to the course of question, to measure knowledge and attitude variables include interval scale of 1 to 3 each with scoring criteria less, moderate and good.

The population of research are those all dog owners in the subdistrict Medan Tuntungan totaling 343 households from 9 urban villages. The sampling process was done purposively based on data from the Medan City Health Office Rabies Centre in Medan Tuntungan and Field of Animal Health and Veterinary Public Health in Department of Agriculture and Marine Medan. The total sample was 72 dog owners who have fulfilled inclusion and exclusion criteria.

The collected data were analyzed descriptively to draw conclusions on the socio-demographic, knowledge and attitude of dog owners about rabies and its prevention that influenced their participation. The relationship between characteristic of dog owners and their participation in rabies prevention analyzed by using Pearson's correlation analysis.

\section{RESULT AND DISCUSSION}

\section{A. Socio-demographic characteristics of the dog owners}

A total of 72 dog owners were visited. The sociodemographic characteristics of respondents are shown as follows: The majority of the respondents was male $(63,9 \%)$; adult aged between 25-49 years $(83,3 \%)$; Christian religion (79,2\%); and Bataknese ethnicity (87,5\%). Most respondent's income was found below the Minimum Wage Medan City in 2017 (54\%); and almost 58\% had graduated from senior high school. About $76 \%$ of respondents owned domestic dogs; the median numbers of humans and dogs per household were 5.0 humans (mean 5,1; range: 1-9) and 2.0 dogs (mean 2.4; range: 1-10); and had children in the household (70,8\%). The majority of dog owners $(69,4 \%)$ indicated that they kept dogs to keep their homes and property and kept their fields to chase away wild animals that destroy their crops; about $55,5 \%$ answered their dogs had bite people; and only $34,7 \%$ of respondents answered that they knew there had been rabies cases in their region.

\section{B. Knowledge of the risk factors, prevention in humans, and control of rabies}

Respondents' knowledge includes everything that the respondent knows about rabies, factors related to the risk, spread of rabies disease, symptoms of rabies disease in dog and humans, prevention, and control of rabies disease. Based on the frequency distribution tabulation of respondents knowledge variables, after data processing has been done, it is known that the knowledge of respondents about rabies disease is in the moderate category, that is 42 respondents $(58,3 \%)$.

TABLE I

FREQUENCY DISTRIBUTION OF RESPONDENTS BASED ON KNOWLEDGE ABOUT THE RABIES PREVENTION IN SUB DISTRICT MEDAN TUNTUNGAN 2017

\begin{tabular}{|c|l|c|c|}
\hline No. & \multicolumn{1}{|c|}{ Knowledge } & f & \% \\
\hline 1 & Good & 28 & 38,89 \\
\hline 2 & Moderate & 42 & 58,33 \\
\hline 3 & Less & 2 & 2,78 \\
\hline \multicolumn{2}{|c|}{ Total } & 72 & 100 \\
\hline
\end{tabular}

\section{Attitudes of rabies prevention}

Attitude is the tendency of respondent to respond (positively or negatively) in rabies prevention program about rabies, including prevention effort in rabies disease dissemination. Here is a description of research results in the form of tabulation of respondent attitude about prevention efforts in the spread of rabies disease. Based on the tabulation of respondent variable distribution, after done data processing, it is known that respondent attitude about prevention effort in spreading of rabies disease mostly in moderate category, that is 37 respondent $(51,3 \%)$.

TABLE II

FREQUENCY DISTRIBUTION OF RESPONDENTS BASED ON ATTITUDE AND PERCEPTION ABOUT THE RABIES PREVENTION IN SUB DISTRICT MEDAN TUNTUNGAN 2017

\begin{tabular}{|c|l|c|c|}
\hline No. & Attitude and Perception & f & \% \\
\hline 1 & Good & 28 & 38,89 \\
\hline 2 & Moderate & 37 & 51,39 \\
\hline 3 & Less Total & 7 & 9,72 \\
\hline \multicolumn{2}{r|}{ Tot } & 72 & 100 \\
\hline
\end{tabular}

\section{Participation of Rabies Prevention}

The participation of the head of household in rabies prevention describes of the participation in implementing the rabies disease prevention program which includes the giving and reboosting of vaccinations to their dogs, binding their dogs with chains no longer than 2 meters, muzzle it when go out from house, and reported the family who is being bitten by dog to Community Health Centre. After done data processing 
it is known that the participation of respondents in prevention of rabies disease is in the moderate category, there is 50 respondents $(69,44 \%), 9$ respondents $(12,5 \%)$ is in the low category, but only 13 respondents $(18,06 \%)$ is in the good category in their participation.

TABLE III.

FREQUENCY DISTRIBUTION OF RESPONDENTS BASED ON PARTICIPATION FOR THE RABIES PREVENTION IN SUB DISTRICT MEDAN TUNTUNGAN 2017

\begin{tabular}{|c|l|c|c|}
\hline No. & \multicolumn{1}{|c|}{ Knowledge } & f & \% \\
\hline 1 & Good & 13 & 18,06 \\
\hline 2 & Moderate & 50 & 69,44 \\
\hline 3 & Less Total & 9 & 12,50 \\
\hline \multicolumn{2}{|c|}{ T2 } & 100 \\
\hline
\end{tabular}

Based on the answers from questionnaires then obtained data, over $75 \%$ of respondents owned domestic dogs (average of 2 dogs per household), more than $68 \%$ knew that rabies is transmitted through dog bites, but around 26,39\% of respondents would seek treatment after a suspect bite to rabies center in Community Health Centre and only 23,61\% were aware of the need for prompt wound cleansing after a bite. As much as $50 \%$ of respondents knew of dog vaccination as a means to control rabies, but only $37,5 \%$ vaccinated their dogs although they know that annual dog vaccination activities have been implemented to vaccinate all dogs free of charge.

To analyze the characteristic relationship of dog owners that includes age, education, income, knowledge and attitude with participation in rabies prevention program, correlation analyze was also done using Pearson's correlation product moment analysis, with result are presented in Table 4.

TABLE IV.

RESULT OF PEARSON CORRELATION ANALYSIS BETWEEN OF CHARACTERISTIC OF DOG OWNER WITH THEIR PARTICIPATION IN RABIES PREVENTION

\begin{tabular}{|c|l|l|c|}
\hline No. & \multicolumn{1}{|c|}{ Variabel } & $\begin{array}{c}\text { Pearson } \\
\text { Correlation }\end{array}$ & $\begin{array}{c}\text { Sig. } \\
\text { (2-tailed) }\end{array}$ \\
\hline 1 & Education & $0,282^{*}$ & 0,016 \\
\hline 2 & Income & $-0,133$ & 0,265 \\
\hline 3 & Knowledge & $0,610 * *$ & 0,000 \\
\hline 4 & Attitude & $0,677 * *$ & 0,000 \\
\hline *. Correlation is significant at the value $p<0.05$ & \\
**. Correlation is significant at the value $p<0.01$ &
\end{tabular}
n

Based on the table it can be seen that there is a strong significant correlation between knowledge, attitude $(\mathrm{p}<0,01)$ and a significant correlation on educational $(\mathrm{p}<0.05)$ of $\operatorname{dog}$ owners with their participation in rabies prevention.

The high rates of rabies case in an area depend on several factors, such as awareness of the community in dog raising (routine vaccination and not letting pets roam haphazardly), community knowledge about the dangers of rabies disease, awareness and willingness to report cases of ABTR, and migration of people whom bringing their pet dogs from one area to another [2]. Rabies is a disease of both rural and urban areas. However, most rabies patients in Medan Tuntungan do not seek proper PEP in health-care facilities. Community participation is an essential element of rabies disease control programme [6]. Education, knowledge and attitudes that influence participation of dog owners on rabies prevention show this area urgently need a health promotion that contains Information, Education and Communication (IEC) activities for rabies control to educate the public about the epidemiological features of rabies and simple precautions that can protect the individual and bring about a reduction in the overall incidence of rabies. Communities must be made aware of the importance of practices such as responsible dog ownership and proper washing of wounds after animal bites. Health promotion should be targeted and adapted to local social culture to facilitate IEC submission $[18,19,20]$.

Characteristic variable of dog owners which most respondent's income was found below the Minimum Wage Medan City have no influence to their participation in rabies prevention program is income variable $(p=0,265)$, because they have more worried if their dogs bite others, then the cost of treatment of dog bites becomes the responsibility of pet dog owners. Another reason of some of the respondents, they claimed to worry that their child who likes to play with their pet dog will get rabies disease if the dog was not vaccinated.

\section{CONCLUSION}

1. The participation of respondents in prevention of rabies disease is in the moderate category is 50 respondents $(69,44 \%), 9$ respondents $(12,5 \%)$ is in the low category, but only 13 respondents $(18,06 \%)$ is in the good category in their participation.

2. There is a strong significant correlation between knowledge, attitude $(\mathrm{p}<0,01)$ and a significant correlation on educational $(\mathrm{p}<0.05)$ of dog owners with their participation in rabies prevention.

3. Characteristic variable of dog owners which have no influence to their participation in rabies prevention program is income variable $(\mathrm{p}=0,265)$.

\section{SUGGESTION}

1. Case of Animal Bites Transmitting Rabies (ABTR) handling can be done by optimizing the Rabies Center at the Community Health Center in sub district Medan Tuntungan.

2. Advocacy programs are needed to generate public awareness and political commitment for rabies control, make an effective system for distributing information so that dog owners are provided with timely information on the vaccination schedule and the provision of dog owners and vaccinators with a technique or skill to catch and restrain dogs.

3. Intersectoral collaboration between the medical sector, veterinary, and integration of local authorities to ensure the availability of preventative service, also the public health to conduct Health promotion of rabies prevention program within the community on the following areas: the danger of rabies and mode of transmission to humans; the importance and usefulness of washing the animal bite wound with plenty of soap and water; the importance of seeking health facilities following animal bites injuries or exposures to suspected/rabid animals; and providing community support and participation for dog rabies control program. 


\section{REFERENCES}

[1] World Health Organization, Programmes: Rabies, The disease. Jenewa: WHO, 2017.

[2] Pusdatin, Infodatin: Jangan Ada Lagi Kematian Akibat Rabies. Jakarta: Kementerian Kesehatan RI, 2016.

[3] End Rabies Now, The challenge: Over 120 countries re still affected by canine rabies. Manhattan, USA: GARC, 2016.

[4] Kementerian Kesehatan RI, Profil Kesehatan Indonesia Tahun 2016. Jakarta: Kementerian Kesehatan RI, 2016.

[5] Global Alliance for Rabies Control, About GARC: Working for eliminate deaths from Canine Rabies by 2030. Manhattan, USA: GARC, 2014.

[6] World Health Organization, Strategic Framework for Elimination of Human Rabies Transmitted by Dog in The South-East Asia Region. New Delhi: World Health Organization Regional Office for South-East Asia, 2012.

[7] Dinas Kesehatan Provinsi Sumatera Utara, Profil Kesehatan Provinsi Sumatera Utara. Medan: Dinas Kesehatan Provinsi Sumatera Utara, 2015.

[8] Dinas Kesehatan Kota Medan, Laporan Tahunan Program P2 Rabies. Medan: Dinas Kesehatan Kota Medan, 2016.

[9] Badan Pusat Statistik Kota Medan, Statistik Daerah Kota Medan 2016. Medan: Katalog BPS, 2016.

[10] M. Sambo, T. Lembo, S. Cleaveland, H.M. Ferguson, and L. Sikana, "Knowledge, attitudes and practices (KAP) about rabies prevention and control: a community survey in Tanzania," PLoS Neglected Tropical Disease, vol. 8, pp. 10-33, August 2014.
[11] M. Herbert, R. Basha, and S. Thangara, "Community perception regarding rabies prevention and stray dog control in urban slums in India," Journal of Infection and Public Health, vol. 5, pp. 374-380, September 2012

[12] R. Jiangping, Z. Gong, E. Chen, J. Lin, W. Wang, S. Liu, and J. Sun, "Human rabies in Zhejiang Province, China," International Journal of Infectious Diseases vol. 38, pp. 77-82, August 2015.

[13] E. Wera, C.M.M. Mourits, and H. Hogeveen, "Uptake of rabies control measures by dog owners in Flores Island, Indonesia," PLoS Neglected Tropical Disease, vol. 9, pp. 35-58, April 2015.

[14] D. Tenzin, N.K. Rai, B.D. Changlo, S. Tenzin, K. Tsheten, "Community-based study on knowledge, attitudes and perception of rabies in Gelephu, south-central Bhutan," International Health, vol. 4, pp. 210-219, December 2014.

[15] Sugiyono, Metodologi Penelitian Kombinasi. Bandung: CV Alfabeta, 2014.

[16] Supriyadi, Statistik Kesehatan. Jakarta: Penerbit Salemba Media, 2014.

[17] S. Notoadmodjo, Promosi Kesehatan dan Perilaku Kesehatan. Jakarta: Rineka Cipta, 2012.

[18] C. Fertman and D.D. Allensworth, Health Promotion Program. USA: Jossey Bass, 2010.

[19] K. Tones and J. Green, Health Promotion: Planning and Strategies. London: SAGE publications, 2012.

[20] J.F. Mc Kenzie, B.L. Neiger, and R. Thackeray, Planning, Implementing and Evaluating Health Promotion Program. USA: Pearson/ Benjamin $\quad$ Cummings, 2009. 